\title{
Stresses in lithium disilicate crowns and zirconia implants in patients with bruxism:
}

\section{An in silico study}

Tensões em coroas de dissillicato de lítio e implantes de zircônia em pacientes com bruxismo: Um estudo in silico

Tensiones en coronas de disilicato de litio e implantes de zirconia en pacientes con bruxismo: Un estudio in silico

Marina Denardi Patricio

ORCID: https://orcid.org/0000-0002-9527-3209

São Leopoldo Mandic, Brazil

E-mail: ma_denardi@hotmail.com

Ricardo Armini Caldas

ORCID: https://orcid.org/0000-0002-5362-4744 Santa Catarina Federal University, Brazil ricardo.caldas@ufsc.br

Milton Edson Miranda

ORCID: https://orcid.org/0000-0002-5410-6500 São Leopoldo Mandic, Brazil memiranda@memiranda.com.br

Karina Andrea Novaes Olivieri ORCID: https://orcid.org/0000-0001-8843-8901 São Leopoldo Mandic, Brazil karina_olivieri@hotmail.com Willian Cunha Brandt

ORCID: https://orcid.org/0000-0002-6362-0499 Santo Amaro University, Brazil williamcbrandt@yahoo.com.br

Rafael Pino Vitti

ORCID: https://orcid.org/0000-0001-6366-5868 Herminio Ometto University Center, Brazil rafapvitti@gmail.com

\begin{abstract}
The aim of this study was to analyze by finite element analysis the influence of the use occlusal splints in rehabilitation with zirconia implant under oblique and vertical masticatory loads. Four models were developed to simulate a clinical of absence of a premolar (element 45) replaced by zirconia implant and lithium disilicate crown. Four groups were created, SP-V without occlusal splint and vertical load; CP-V with occlusal splint and vertical load; SP-O without occlusal splint and oblique load; CP-O with occlusal splint and oblique load. The four models were built using a software (SolidWorks, SolidWorks Corporation). A load of $300 \mathrm{~N}$ to $45^{\circ}$ (oblique) and $90^{\circ}$ (vertical) applied to the long axis of the whole structure. The maximum principal stress (tensile) and minimum principal stress (compression), as well as the total deformation in the implant, occlusal splint, crown and bone tissue were evaluated quantitatively and qualitatively. The $\mathrm{CP}-\mathrm{V}$ and $\mathrm{CP}-\mathrm{O}$ groups presented the lowest stress intensities, which were homogeneously distributed in all structures analyzed. On other hand, SP-V and SP-O groups presented highest stress distributed in a heterogeneous way. Groups with occlusal splint (CP-V and CP-O) also showed lower deformation than groups without occlusal splint (SP-V and SP-O). It's concluded the use of occlusal splint minimizes the stresses and deformation promoted by oblique and vertical occlusal loads of up $300 \mathrm{~N}$ in implanted lithium disilicate crown supported by zirconia implants.
\end{abstract}

Keywords: Ceramics; Dental implantation; Finite element analysis.

\section{Resumo}

O objetivo neste estudo foi verificar por meio da análise de elementos finitos a influência do uso de placas oclusais na reabilitação com implante de zircônia sob cargas mastigatórias oblíquas e verticais. Quatro modelos foram desenvolvidos para simular um quadro clínico de ausência de pré-molar (elemento 45) substituído por implante de zircônia e coroa de dissilicato de lítio. Foram criados quatro grupos, SP-V sem placa oclusal e carga vertical; CP-V com placa oclusal e carga vertical; SP-O sem placa oclusal e carga oblíqua; CP-O com placa oclusal e carga oblíqua. Os quatro modelos foram construídos por meio de um software (SolidWorks, SolidWorks Corporation). Uma carga de 
$300 \mathrm{~N} \mathrm{a} 45^{\circ}$ (oblíqua) e $90^{\circ}$ (vertical) aplicada ao longo eixo de toda a estrutura. A tensão principal máxima (tração) e a tensão principal mínima (compressão), bem como a deformação total no implante, placa oclusal, coroa e tecido ósseo foram avaliadas quantitativa e qualitativamente. Os grupos CP-V e CP-O apresentaram as menores intensidades de tensões, distribuídas homogeneamente em todas as estruturas analisadas. Por outro lado, os grupos SP-V e SP-O apresentaram maiores tensões distribuídas de forma heterogênea. Os grupos com placa oclusal (CP-V e CP-O) também apresentaram menor deformação do que os grupos sem placa oclusal (SP-V e SP-O). Conclui-se que o uso da placa oclusal minimiza as tensões e deformações promovidas por cargas oclusais oblíquas e verticais de até $300 \mathrm{~N}$ em coroas de dissilicato de lítio implantadas suportadas por implantes de zircônia.

Palavras-chave: Cerâmica; Implantação dentária; Análise de elementos finitos.

\section{Resumen}

El objetivo de este estudio fue analizar mediante análisis de elementos finitos la influencia del uso de férulas oclusales en rehabilitación con implante de circonio bajo cargas masticatorias oblicuas y verticales. Se desarrollaron cuatro modelos para simular una clínica de ausencia de un premolar (elemento 45) reemplazado por implante de circonio y corona de disilicato de litio. Se crean cuatro grupos, SP-V sin férula oclusal y carga vertical; CP-V con férula oclusal y carga vertical; SP-O sin férula oclusal y carga oblicua; CP-O con férula oclusal y carga oblicua. Los cuatro modelos se crearon con un software (SolidWorks, SolidWorks Corporation). Una carga de $300 \mathrm{~N} \mathrm{a} 45^{\circ}$ (oblicua) y $90^{\circ}$ (vertical) aplicada al eje longitudinal de toda la estructura. Se evaluaron cuantitativa y cualitativamente la tensión principal máxima (tracción) y la tensión principal mínima (compresión), así como la deformación total en el implante, férula oclusal, corona y tejido óseo. Los grupos CP-V y CP-O presentaron las menores intensidades de estrés, las cuales se distribuyeron homogéneamente en todas las estructuras analizadas. Por otro lado, los grupos SP-V y SP-O presentaron mayor estrés distribuido de forma heterogénea. Los grupos con férula oclusal (CP-V y CP-O) también mostraron una menor deformación que los grupos sin férula oclusal (SP-V y SP-O). Se concluye que el uso de férula oclusal minimiza las tensiones y deformaciones promovidas por cargas oclusales oblicuas y verticales de hasta $300 \mathrm{~N}$ en coronas implantadas de disilicato de litio soportadas por implantes de zirconia.

Palabras clave: Cerámica; Implantación dental; Análisis de elementos finitos.

\section{Introduction}

The titanium implants have elevated clinic success rates (Galvão et al., 2016) However, the main titanium’s implant disadvantage is its color, which can be seen either through soft tissues or gingival recession, therefore it compromises the restoration's esthetic. The zirconia-based ceramics are restored esthetics materials that can be used as an alternative material to titanium (Hashim et al., 2016). These ceramics have both optical and mechanical properties similar to the natural tooth (Andreiotelli et al., 2009). In addition, they present elevated physical properties, such as being resistant to bending, fracture toughness and hardness (Lee et al., 2013).

The elevated physical properties of zirconia are related to the presence of yttrium oxide (yttria). Yttria-stabilized polycrystalline tetragonal zirconia (Y-TZP) presents a volumetric expansion of its tetragonal crystals under high loads. This expansion causes stress compression that opposes: the applied load, the possible crack formation, and propagation (Hannink et al., 2000).

Patients with bruxism are constantly with dental and prosthetic elements under high occlusal load (Boulad et al., 2019). Thus, bruxism is an etiological oral rehabilitations failure factor (Zhou et al., 2016). The manufacture and usage of the occlusal splint are simple procedures, safe, and non-invasive to the bruxism treatment. The splint sets the temporomandibular joint (TMJ) in a stable joint position by protecting the teeth from excessive chewing loads enhanced by bruxism (Boulad et al., 2019).

Although bruxism is a deleterious habit that affects about $80 \%$ of the population (Zhou et al., 2016), only few data are available in the literature on how the elevated stress caused by bruxism affects zirconia implant-supported prostheses and the adjacent bone tissue. Furthermore, due to the increasing of ceramic implant systems commercially available and the increasing demand for highly esthetical restorations, studieshas shown substantial interest for the dental surgeon to assess the prognosis of the rehabilitative treatment.

Thus, the aim of this study is to evaluate the influence of the occlusal plate used in a rehabilitated mandible with 
zirconia implant under oblique and vertical masticatory loads by using the finite element method. The tested hypothesis were that the use of an occlusal plate would decrease the stresses caused on the implant, crown, and adjacent bone tissue.

\section{Methodology}

The entire finite element analysis procedure consisted of three stages: preprocessing, processing and postprocessing for analysis results.

On the preprocessing, the fabrication of the geometric model was carried out and information regarding the material's mechanical properties used in the model construction was added too. The structure of the model was split in finite number of elements, which were interconnected through nodal points that lie in the three-dimensional coordinate system. The resulting set was called mesh.

Four three-dimensional models were developed, reproducing a clinical situation with the absence of a mandibular premolar (element 45). This tooth was replaced by a zirconia implant and lithium disilicate crown on implants in order to stimulate both oblique and vertical occlusal loading in bone-integrated implants.

With the aim of making three-dimensional maxilla bone model, imagens of the artificial toothed mandible were obtained through a computed tomography (I-CAT Cone Beam 3D Dental Imaging System, Imaging Sciences International, Hatfield, PA, USA). In addition, finite elements were developed with a software aid (SolidWorks, SolidWorks Corporation, Concord, MA, USA). Lastly, an IPS emax lithium disilicate prosthetic crown (Ivoclar, Vivadent) was virtually reproduced to all groups using an image previously obtained by computed microtomography. The models were distributed to the respective study groups (Figure 1):

SP-V: without plate and vertical load.

CP-V: with plate and vertical load.

SP-O: without plate and oblique loading.

CP-O: with plate and oblique loading.

Figure 1. Representation of models in finite elements. (A) SP-V; (B) CP-V; (C) SP-O; (D) CP-O.

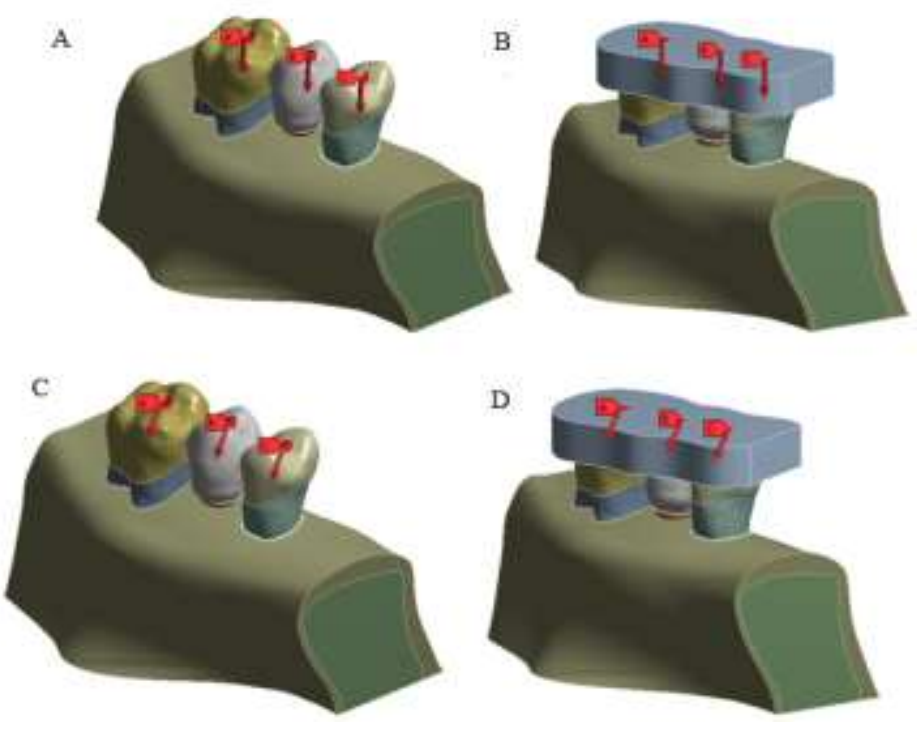

Source: Authors.

After the models being produced, they were transferred to the ANSYS Workbench 14.0 software (Swanson Analysis 
Systems Inc., Houston, PA, EUA) to perform the finite element analyses. The static structural analyses option was chosen to perform the simulations.

The materials were considered isotropic, homogeneous, and linearly elastic. The total of elasticity modulus and Poisson's ratio described in Table 1 were transferred to the software and all connections were considered closely bonded (without friction).

Table 1. Mechanical properties of the materials used.

\begin{tabular}{lll}
\hline Material & Elasticity Modulus (Gpa) & Poisson's Coefficient \\
\hline Cortical bone & $13,7^{\mathrm{a}}$ & $0,30^{\mathrm{a}}$ \\
Cancellous bone & $1,37^{\mathrm{a}}$ & $0,30^{\mathrm{a}}$ \\
Zirconia & $200^{\mathrm{a}}$ & $0,31^{\mathrm{a}}$ \\
Lithium disilicate & $68^{\mathrm{b}}$ & $0,24^{\mathrm{b}}$ \\
Acrylic resin & $2,65^{\mathrm{c}}$ & $0,35^{\mathrm{c}}$ \\
\hline
\end{tabular}

${ }^{\mathrm{a} C ̧ a g l a r ~ e t ~ a l . ~(2011) ; ~}{ }^{\mathrm{b}}$ Ereifej et al. (2011); ${ }^{\mathrm{c}}$ Vieriu et al. (2015).

Some measures were taken to avoid stress concentration errors existing in the meshes, therefore, improving its efficiency such as the refinement at the interfaces between solids with a maximum element size of $0.2 \mathrm{~mm}$, element growth factor of 1.2, and elements being 10-node tetrahedra. The meshes for the finite element analyses were produced and their integrity related to the quality of the elements in the interested regions were evaluated.

Afterwards, the processing was computationally performed simulating the application of a $300 \mathrm{~N}$ load at $45^{\circ}$ (oblique) and $90^{\circ}$ (vertical) to the extended axis of the entire structure.

Finally, the post-processing consisted of analysing the model and comparing them quantitatively and qualitatively using the obtained and evaluated results through maximum principal stress (tension), minimum principal stress (compression), and total deformation in the implant, plate, crown, and bone tissue.

\section{Results}

The Figure 2 shows the representative model of the group, with the plate and oblique loading (CP-O). The arrow represents the stress distributed (total strain) in the occlusal plate, teeth (46 and 44), and implanted crown (45). The stresses homogeneously distributed itself to every dental element (44, 45 and 46), and the highest total strain ( 0.06 MPa) was found in the occlusal plate near the tooth 44 and in the crown of tooth 44 . 
Figure 2. Representation of the CP-O group.

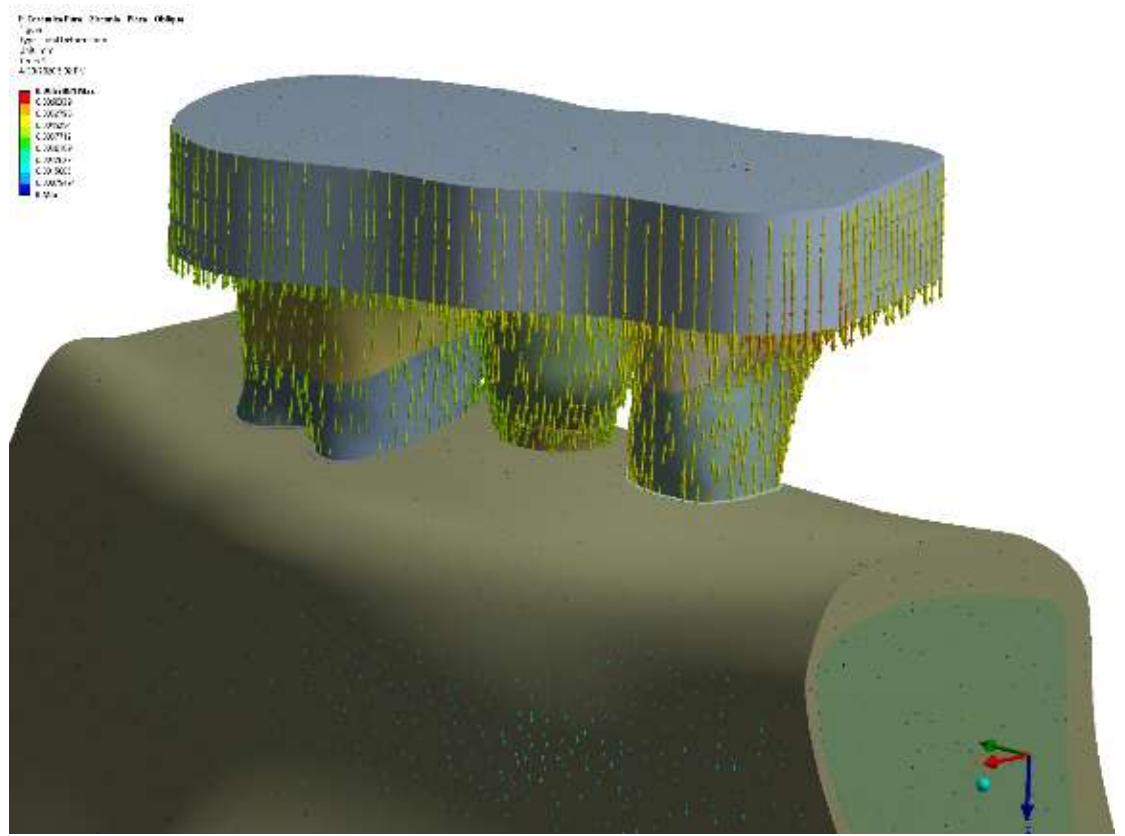

Source: Authors.

In $\mathrm{CP}-\mathrm{O}$ group, the maximum principal stress was centred in the bone near the cervical implant region and above the first thread with a maximum intensity of 2.7 MPa. In the implant itself, the stress was centred in its apical region (16.0 MPa) (Figure 3).

Figure 3. Distribution of the maximum principal stress in the bone tissue (A and B) and in the implant (C) for the CP-O group.

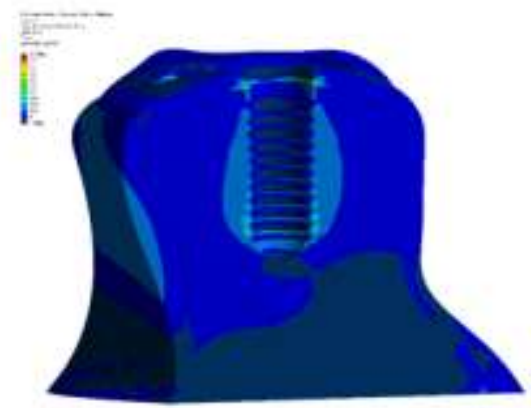

A

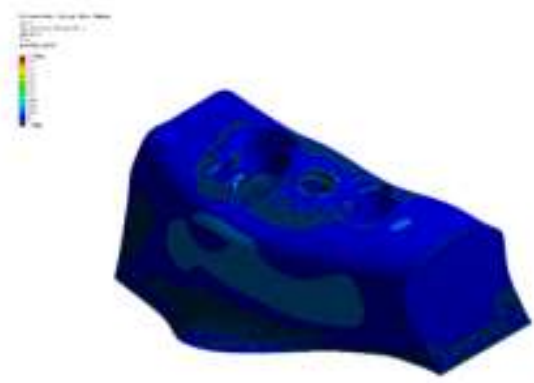

B

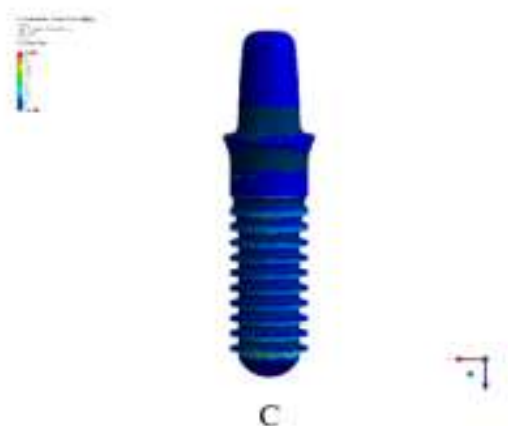

Source: Authors. 
However, the minimum principal stress in CP-O group was centred in the alveolar bone crest and apical bone region (0.12 MPa). Regarding the implant, the minimum principal stress was centred in every thread and mainly in the apical implant region, with a maximum intensity of 3.0 MPa (Figure 4).

Figure 4. Distribution of the minimum principal stress in the bone tissue (A and B) and in the implant (C) for the CP-O group.

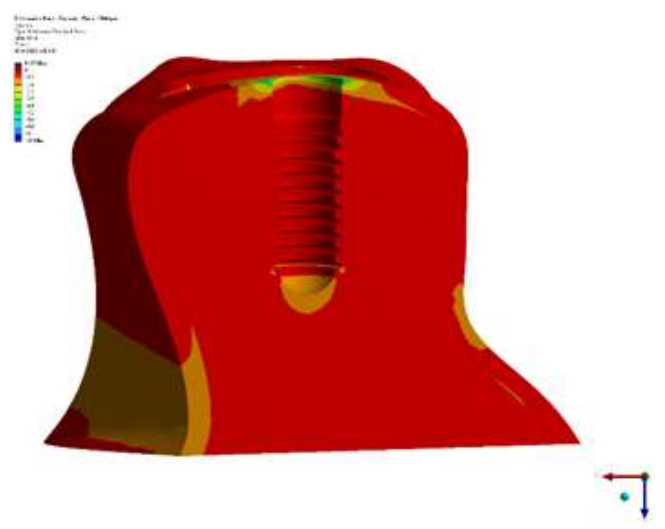

A

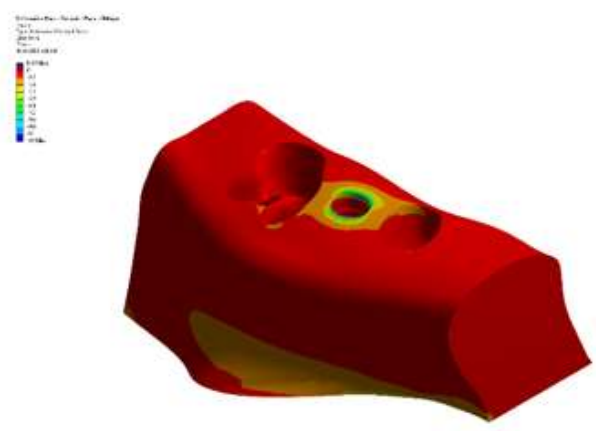

B

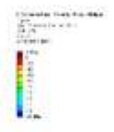

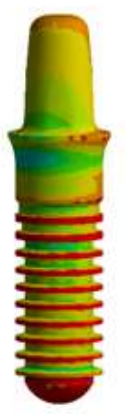

C

Source: Authors.

The representative group model with plate and vertical load (CP-V) shows the distributed stress (arrows), representing the total deformation in the occlusal plate, teeth (46 and 44), and implant crown (45). The stress distributes itself homogenously to every dental element and the highest total strain $(\sim 0,09 \mathrm{MPa})$ was found in the occlusal plate near the tooth 44 and in the crown of the tooth 44 (Figure 5). 
Research, Society and Development, v. 10, n. 5, e29710515099, 2021

(CC BY 4.0) | ISSN 2525-3409 | DOI: http://dx.doi.org/10.33448/rsd-v10i5.15099

Figure 5. Representation of the CP-V group.

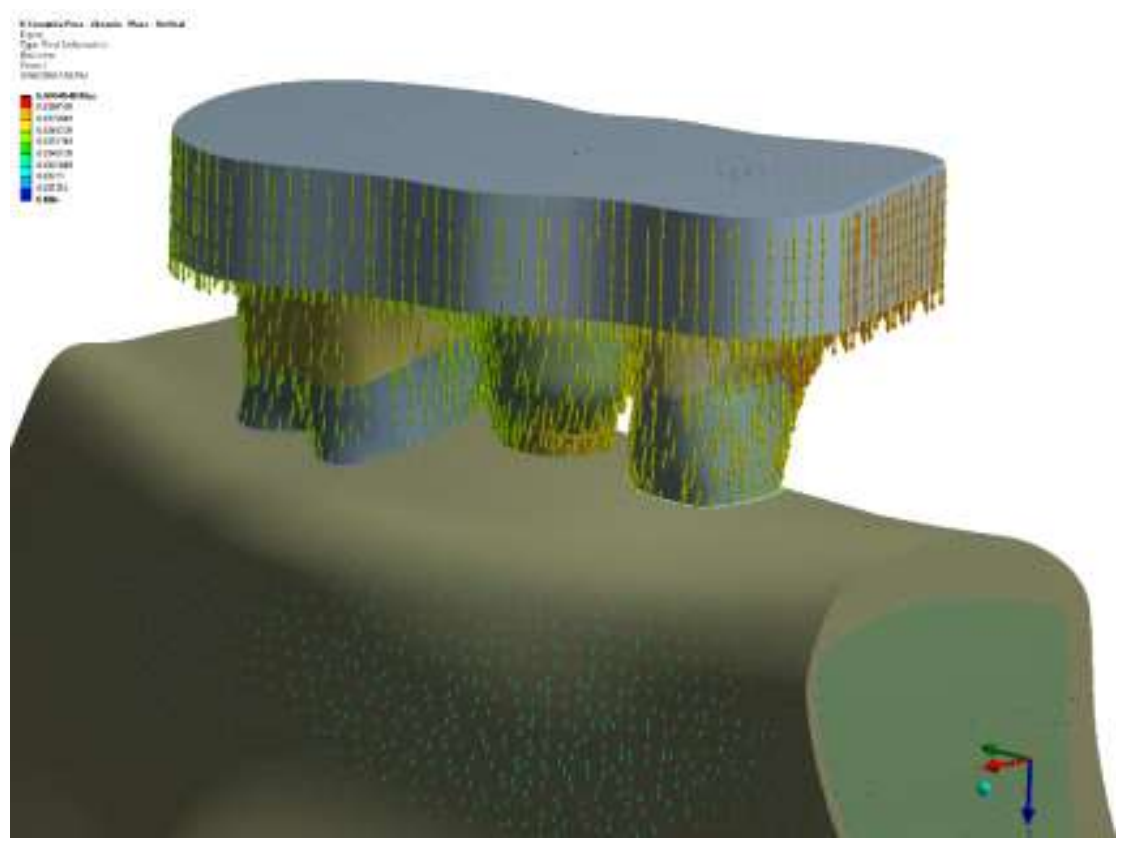

Source: Authors.

In the $\mathrm{CP}-\mathrm{V}$ group, the maximum principal stress also centred itself in the bone near the cervical implant region, above the first thread (similar to the CP-O group). However, the maximum intensity stress was 4.0 MPa, likewise the CP-O group. The stress on the implant centred itself on its apical region, after the last thread. Nevertheless, the maximum intensity was 24.0 MPa (Figure 6). 
Figure 6. Distribution of the maximum principal stress in the bone tissue (A and B) and in the implant (C) for the CP-V group.

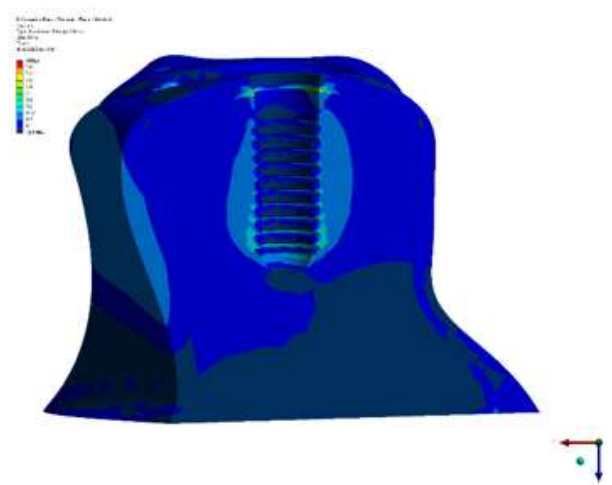

A

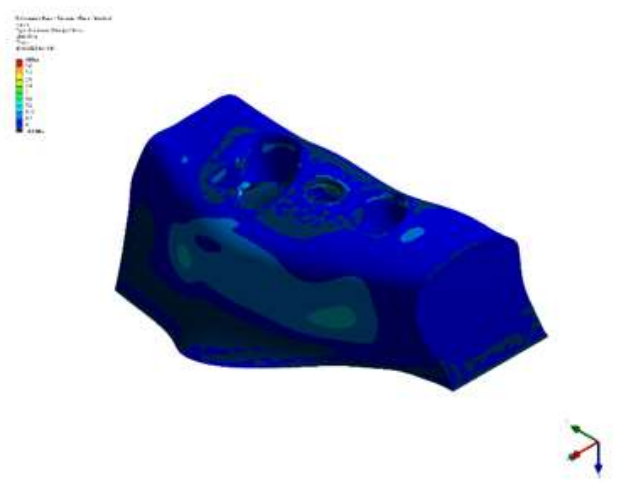

B
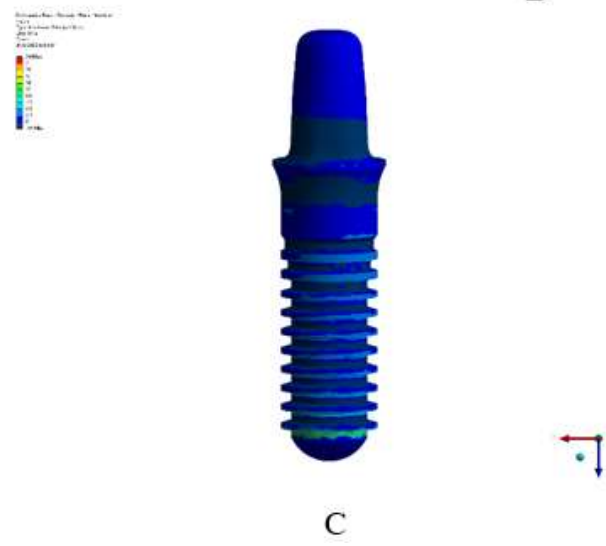

Source: Authors.

Concerning the minimum principal stress, the CP-V group had higher stress concentration in the alveolar bone crest and apical bone region as in CP-O group, yet with a maximum intensity of $0.18 \mathrm{MPa}$. On the other hand, in the implant this stress was centred in every thread and mainly in the apical region of the implant (4.6 MPa) (Figure 7). 
Figure 7. Distribution of the minimum principal stress in the bone tissue (A and B) and in the implant (C) for the CP-V group.

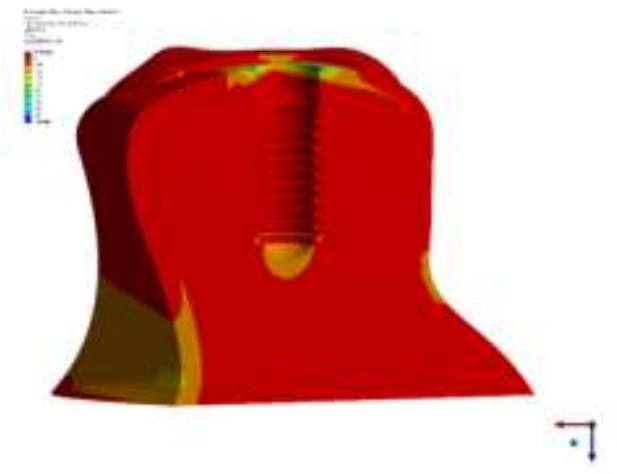

A

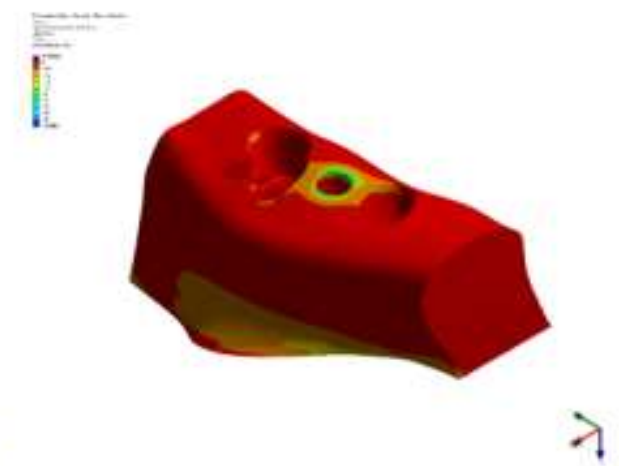

B

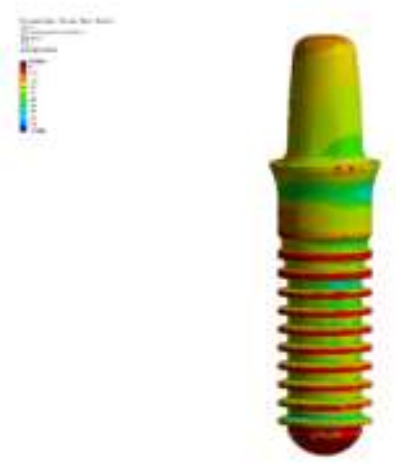

C

Source: Authors.

The groups without plate and oblique loading (SP-O) shows distributed stresses (arrows), representing the total teeth deformation (46 and 44) and crown on implant (45). The stresses heterogeneously distributed itself, concentrating on the implant (45) with the highest total strain ( 00.46 MPa) in the occlusal third of the tooth crown (45) (Figure 8). 
Figure 8. Representation of the SP-O group.

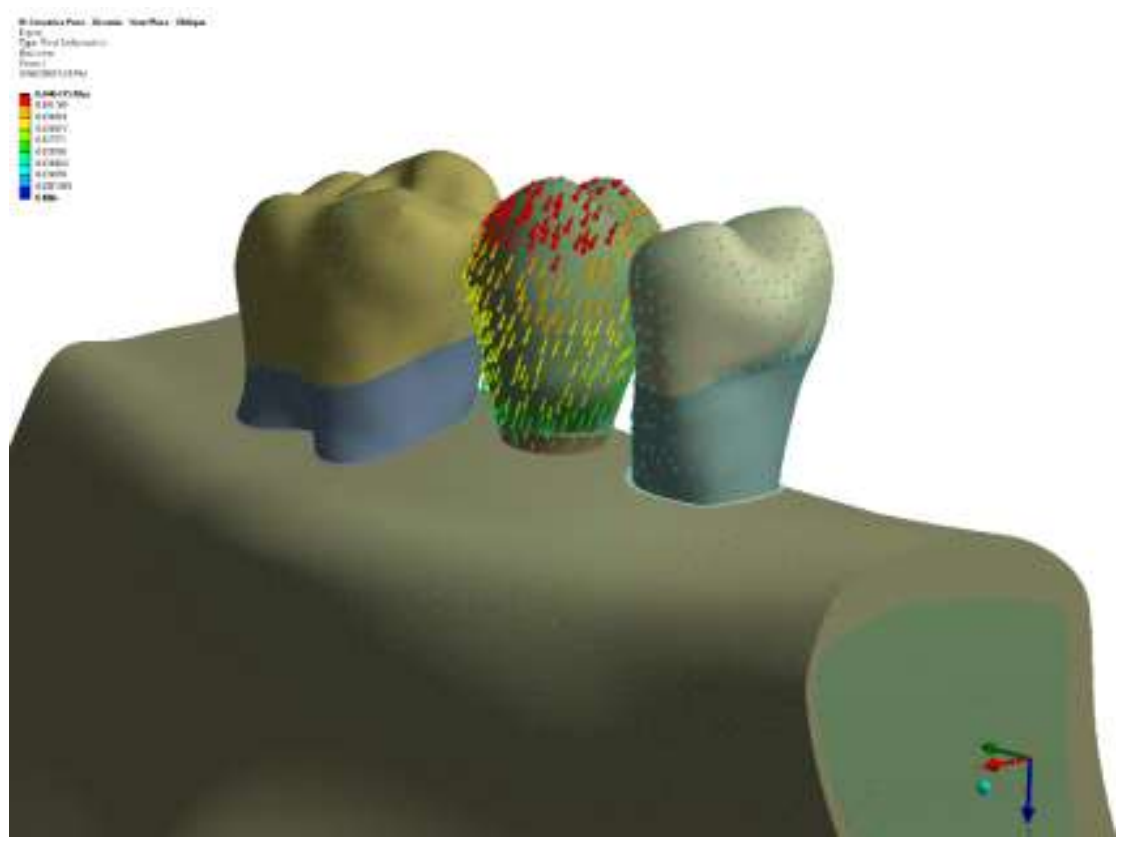

Source: Authors.

The Figure 9 shows a maximum principal stress distribution in SP-O group. On the bone side, the stress was concentrated in the alveolar bone crest covering the lingual face, the maximum intensity stress was 50.0 MPa. On the implant, the stress was concentrated from the cervical third up to the third thread (133.0 MPa).

Figure 9. Distribution of the maximum principal stress in the bone tissue (A and B) and in the implant (C) for the SP-O group.

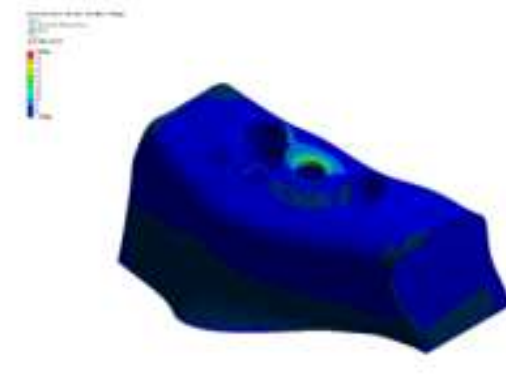

A

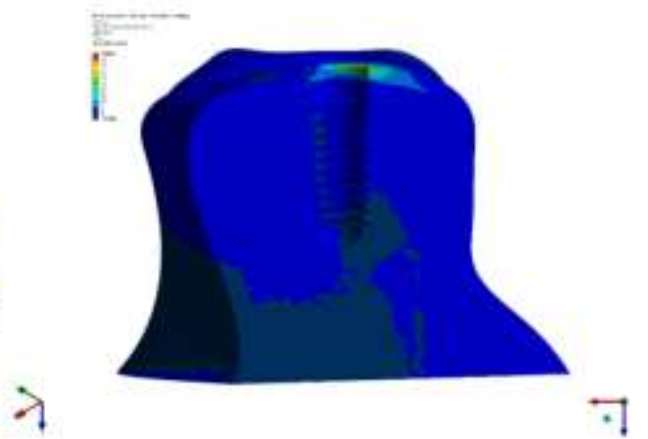

B
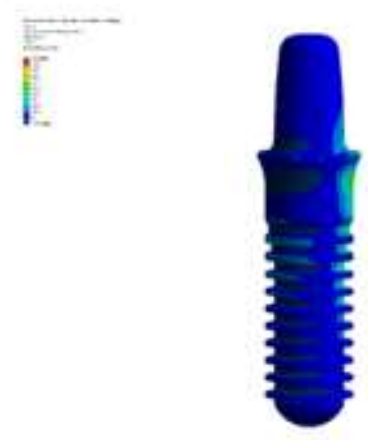

C

Source: Authors. 
The SP-O group had the highest minimum principal stress concentration on the alveolar bone crest regarding to both buccal and lingual surfaces with a maximum intensity of 12.0 MPa in the lingual side. On the implant, the stress dispersed throughout the structure with a maximum intensity of $32,7 \mathrm{MPa}$ on the implant cervical region regarding the lingual side (Figure 10).

Figure 10. Distribution of the minimum principal stress in the bone tissue (A and B) and in the implant (C) for the SP-O group.

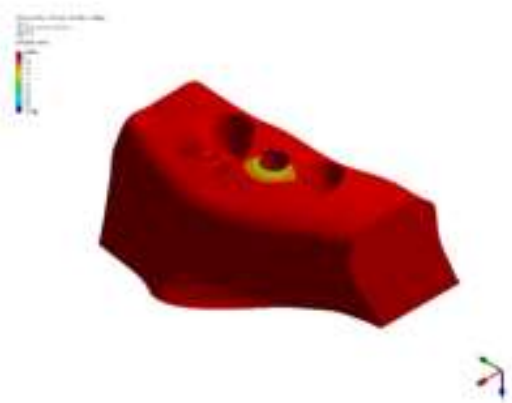

A

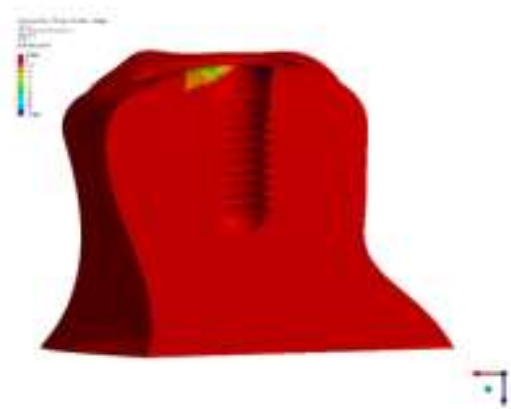

B

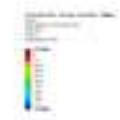

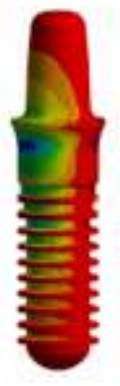

C

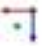

Source: Authors.

The Figure 11 show the distributed stresses (arrow) in the group without plate and vertical load (SP-V). As in the SPO group, these stresses distribute itself heterogeneously, concentrating in the crown occlusal third of tooth 45 . However, the total maximum strain is equal to $\sim 0.006 \mathrm{MPa}$. 
Figure 11. Representation of the SP-V group.

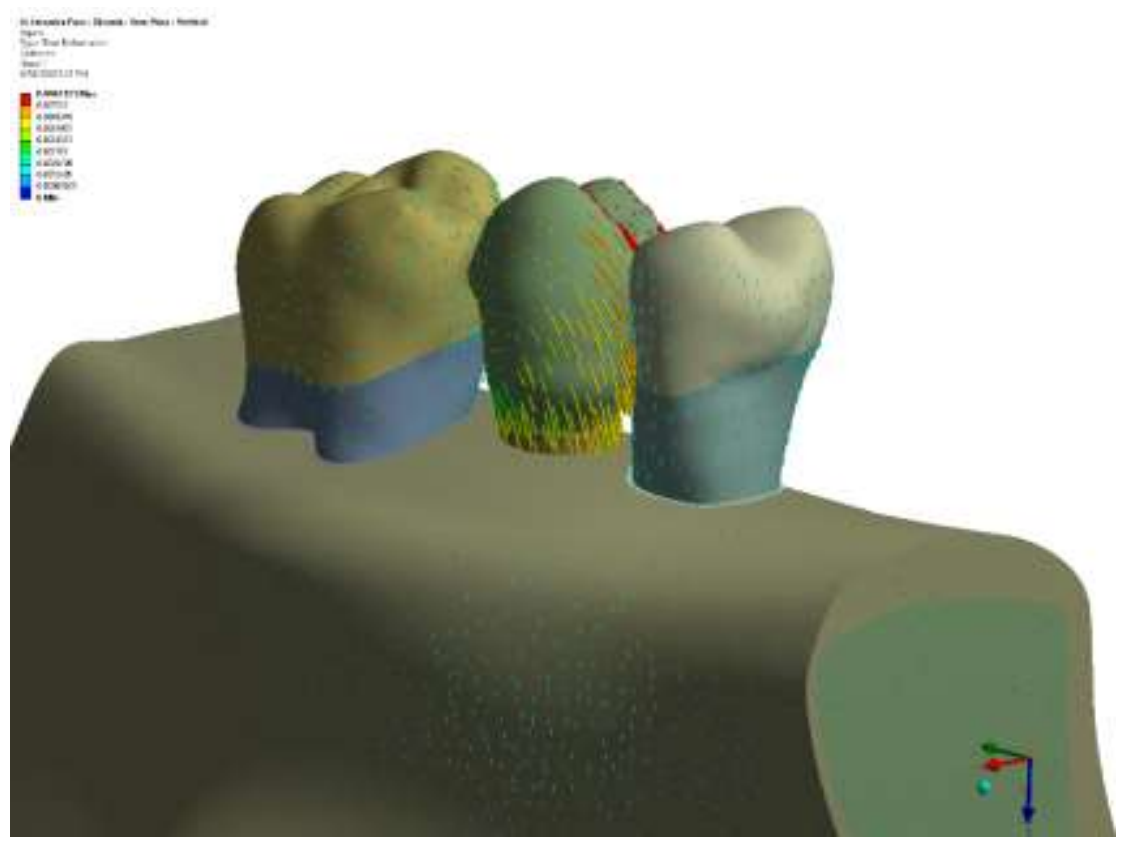

Source: Authors.

On the bone, the maximum principal stress was also concentrated in the alveolar bone crest, covering the lingual face as the SP-O group. However, the maximum intensity of this stress was 3.9 MPa. The stress on the implant was dispersed through all threads, concentrating a piece more in the apical third (last thread), in a maximum intensity of $16.0 \mathrm{MPa}$ (Figure 12).

Figure 12. Distribution of the maximum principal stress in the bone tissue (A and B) and in the implant (C) for the SP-V group.

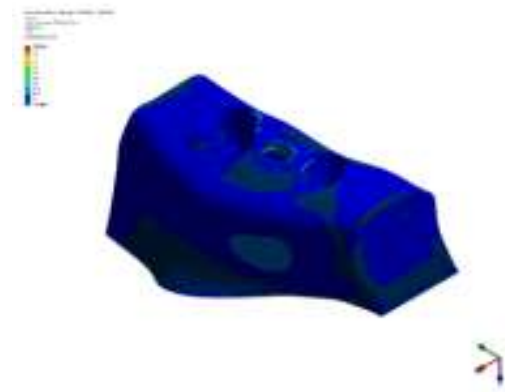

A

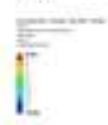

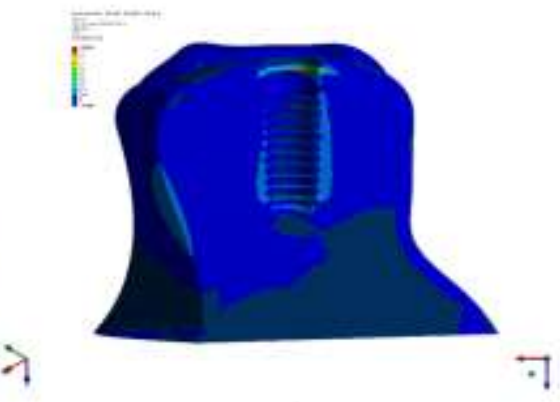

B

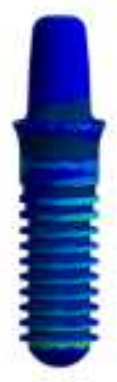

C

Source: Authors. 
The SP-V group showed the minimum principal stress concentrated in the alveolar bone crest on the buccal and lingual surfaces, in a maximum intensity of $0.13 \mathrm{MPa}$ in relation to the lingual side. On the implant, the stress was dispersed through all the structure in a maximum intensity of 3.2 MPa (Figure 13).

Figure 13. Distribution of the minimum principal stress in the bone tissue (A and B) and in the implant (C) for the SP-V group.

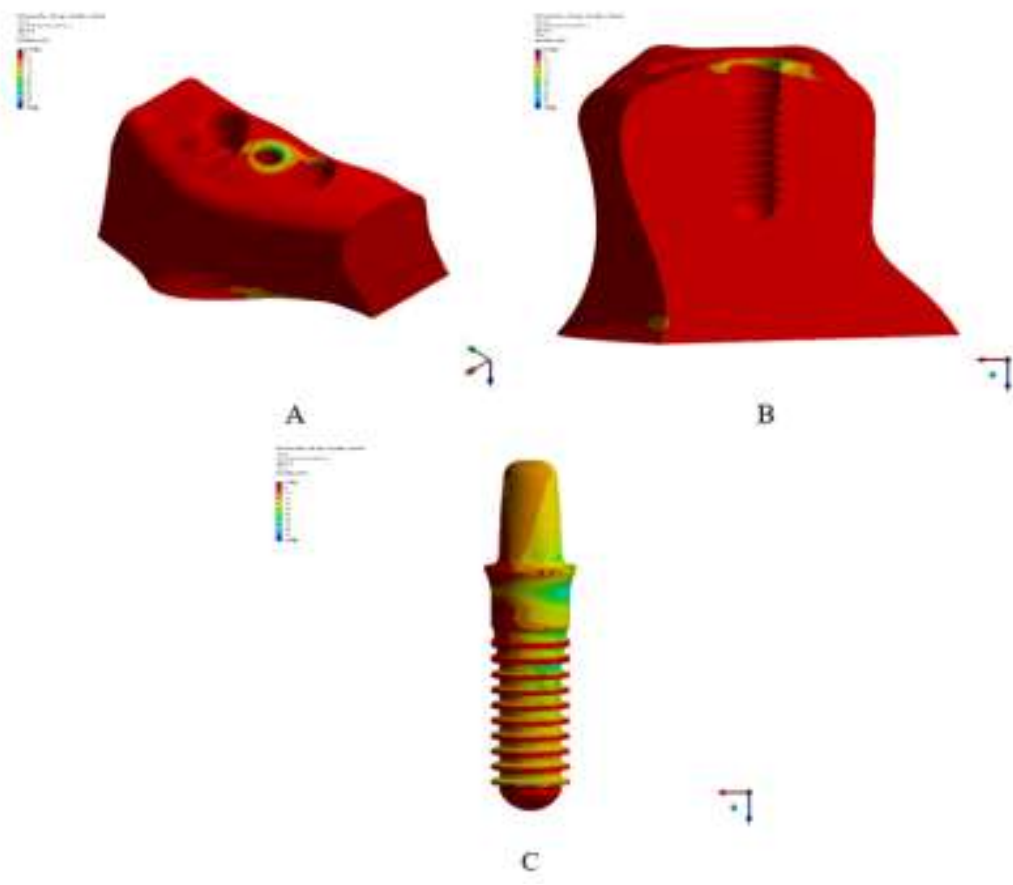

Source: Authors.

\section{Discussion}

The tested hypothesis was accepted due to both groups with occlusal plate ( $\mathrm{CP}-\mathrm{V}$ and $\mathrm{CP}-\mathrm{O})$ has shown lower and better stress distribution. The CP-O group showed homogeneous strain result in tooth 44 due to its smaller area when compared to the crowns of teeth 45 and 46 . On the same group, the maximum principal stress was concentrated in the bone near the implant cervical area above the first thread. In other words, in the crown-implant, where the most fragile assembly area is found (Lombardo et al., 2019; Bergamo et al., 2021). Concerning the implant, this stress was concentrated in its apical area and the minimum principal stress on this groups was concentrated in the alveolar bone crest and on the apical bone region due to the compression stress. The same situation happened in the implant, which the same stress was concentrated in every thread and mainly in the implant apical area.

Regarding the group $\mathrm{CP}-\mathrm{O}$, the quantitative stress results were lower than the $\mathrm{CP}-\mathrm{V}$ group due to the loading type (oblique). In the CP-V group, the maximum principal stress was also concentrated in the bone, near the cervical implant region, above the first thread, yet with greater intensity. Just as the CP-O group, the stress on the implant was concentrated in its apical area, after the last thread, but in greater intensity too. Regarding the minimum principal stress, the CP-V group had higher concentration in both the alveolar bone crest and apical bone area, similar to the CP-O group, yet in a higher intensity. The stress on the implant was concentrated in every thread, mainly in the apical implant area.

The stress on the SP-O group was distributed heterogeneously, concentrating itself on the implant (45) in a higher occlusal third tooth crown strain result (45). The result can be explained due to the fact that the implant does not have 
periodontal ligament, which provides the natural teeth to function under the load chewing pressure (Washio et al., 2018; Moga et al., 2021; Ono et al., 2021). On the bone side, we can see that the maximum principal stress is centred in the alveolar bone crest of the lingual face, which is the opposite side of the load applied. This maximum intensity stress was higher than in the CP-O group. On the other hand, this stress was concentrated in the implant from the cervical third until the third thread. The minimum principal stress in the CP-O group was more concentrated in the alveolar bone crest in the buccal and lingual sides, in a higher result on the lingual side.

As in the SP-O group, but lower strain result, these stresses in the SP-V group were also distributed heterogeneously, concentrating in the occlusal third of the tooth crown 45. As well as the SP-O group, the maximum principal stress on the bone was also concentrated on the alveolar bone crest in the lingual surface, however, the maximum intensity of stress was lower in this group. In the implant, this stress was dispersed through all threads, concentrating a piece more in the apical third (last thread). Contrarily, the minimum principal stress was concentrated in the alveolar bone crest, yet with less intensity than in the SP-O group. The occurrence is due to the fact that the load was vertical and not oblique (Moura et al., 2020; Hong et al., 2020; Sesha et al., 2020). Due to the implant does not have a function in the study, this stress was dispersed through all the structure (Hajizadeh, Panahi, 2019; Brandão de Holanda et al., 2020).

Overall, both the implant and the bone tissue showed high stress and strain on the models that the occlusal plate was not applied/used (SP-O and SP-V), which may lead to bone loss and, consequently an implant loss (Brandão de Holanda et al., 2020; Meijndert et al., 2021; Moga et al., 2021). In regard to the crown, the stresses were higher in the groups without plate (SP-O and SP-V) when compared to the groups with plate (CP-O AND CP-V), which may lead to a fracture in the ceramic crown (Lee et al, 2013; Brandão de Holanda et al., 2020; Hafezeqoran et al., 2020).

Lastly, the best results in the pattern groups with occlusal plate are related to the fact that the occlusal plate absorbs the masticatory loads stress (Domanic et al., 2020; Henrique et al., 2020). In addition, there is a decrease of the muscle activity due to the growth in the patient's vertical dimension, stimulated by occlusal plate use (Boulad et al., 2019). The occlusal plate helps the patient to not clench and/or grind the teeth when sleeping and, as a result, these patients become aware of their occlusal problems when awake (Boulad et al., 2019; Henrique et al., 2020). The groups that used the plate showed the lowest stress results, supporting the studies that proves the occlusal plate decreases the stresses caused on teeth and implants by patient with bruxism (Domanic et al., 2020; Henrique et al., 2020).

\section{Conclusion}

The use of occlusal splint minimizes the stresses and deformation promoted by oblique and vertical occlusal loads of up $300 \mathrm{~N}$ in implanted lithium disilicate crown supported by zirconia implants.

\section{References}

Andreiotelli, M., Wenz, H. J., \& Kohal, R. J. Are ceramic implants a viable alternative to titanium implants? A systematic literature review. Clin Oral Implan Res. 20: 32-47.

Bergamo, E. T. P., et al. (2019). Survival of implant-supported resin-matrix ceramic crowns: In silico and fatigue analyses. Dent Mater. 19:S01095641(21)00004-X.

Boulad, J. M. K., et al. (2019). Effects of treatment with nociceptive trigeminal inhibition splints on electromyography in temporomandibular joint disorder patients. J Contemp Dent Pract; 1;20(5):598-602.

Brandão de Holanda, K. A., et al (2011). Biomechanical evaluation of anterior implants associated with titanium and zirconia abutments and monotype zirconia implants. J Prosthodont Res. 65(1):73-77.

Çaglar, A., et al (2011). Three dimensional finite element analysis of titanium and yttrium-stabilized zirconium dioxide abutments and implants. Int J Oral Maxillofac Implants 26: 961-969. 
Research, Society and Development, v. 10, n. 5, e29710515099, 2021

(CC BY 4.0) | ISSN 2525-3409 | DOI: http://dx.doi.org/10.33448/rsd-v10i5.15099

Ereifej, N., Rodrigues, F. P., Silikas, N., \& Watts, D. C. (2011). Experimental and FE shearbonding strength at core/veneer interfaces in bilayered ceramics. Dent Mater 27: 590-597.

Galvão, G. H., et al. (2016). Influence of metal and ceramic abutments on the stress distribution around narrow implants: a photoelastic stress analysis. Implant Dent. 2016; 25: 499-503.

Hajizadeh, F., \& Panahi, S. (2019). Stress and strain distribution patterns in bone around tissue- and bone-level implant-supported mandibular overdentures using three-dimensional finite-element analysis. J Long Term Eff Med Implants. 29(3): 175-181.

Hafezeqoran A, Koodaryan R, Hemmati Y, \& Akbarzadeh A. (2020). Effect of connector size and design on the fracture resistance of monolithic zirconia fixed dental prosthesis. J Dent Res Dent Clin Dent Prospects. 14(4): 218-222.

Hannink, R. H. J., Kelly, P. M., \& Muddle, B. C. (2000). Transformation toughening in zirconiacontaining ceramics. J Am Ceram Soc. 83: $461-487$.

Hashim, D., Cionca, N., Courvoisier, D. S., \& Mombelli, A. (2016). A systematic review of the clinical survival of zirconia implants. Clin Oral Investig. 20: 1403-1417.

Henrique, M. N., et al (2020). Influence of flat occlusal splint on stresses induced on implants for different fixed prosthetic systems. Eur J Prosthodont Restor Dent. 19.

Hong, S. J., et al (2020). Retention force and stress distribution analysis of the cementless double crown-type implant-supported prosthesis. J Prosthet Dent. 29:S0022-3913(20)30718-6.

Lee, S. J., Macarthur, R. X. 4th, \& Gallucci, G. O. (2013). An evaluation of student and clinician perception of digital and conventional implant impressions. $J$ Prosthet Dent. 110 (5): 420-423.

Lombardo, G., et al. (2019). Successful management of peri-implantitis around short and ultrashort single-crown implants: a case series with a 3-year followup. Int J Dent. 15;2019:5302752.

Meijndert, C. M., et al (2021). Alveolar ridge preservation in defect sockets in the maxillary aesthetic zone followed by single-tooth bone level tapered implants with immediate provisionalization: a 1-year prospective case series. Int J Implant Dent. 2021; 19;7(1):18.

Moga, R. A., et al (2021). Compressive stress in periodontal ligament under orthodontic movements during periodontal breakdown. Am J Orthod Dentofacial Orthop. 21:S0889-5406(20)30807-6

Ono, T., et al. (2021). Generation of biohybrid implants using a multipotent human periodontal ligament cell line and bioactive core materials. J Cell Physiol.

Sesha, M. R., (2020). Biomechanical evaluation of stress distribution in subcrestal placed platform-switched short dental implants in d4 bone: in vitro finiteelement model study. J Pharm Bioallied Sci. 12(1):S134-S139.

Vieriu, M., et al. (2015). The validation of an acrylic resin for the completion of biomechanical studies on a mandibular model. Roman J Oral Rehab. 7: 74-79

Washio, K., et al. (2018). In vivo periodontium formation around titanium implants using periodontal ligament cell sheet. Tissue Eng Part A. 24(15-16):12731282.

Zhou, Y., Gao, J., Luo, L., \& Wang, Y. (2016). Does bruxism contribute to dental implant failure? a systematic review and meta-analysis. Clinical Implant Dentistry and Related Research. 18(2): 410-420. 